\title{
Address Module Coordinator
}

National Cancer Institute

\section{Source}

National Cancer Institute. Address Module Coordinator. NCI Thesaurus. Code C51796.

A person who coordinates and manages address and contact information for an

organization. 